\title{
The Historical Role Of The Production Function In Economics And Business
}

David Gordon, University of Saint Francis, USA

Richard Vaughan. University of Saint Francis, USA

\begin{abstract}
The production function explains a basic technological relationship between scarce resources, or inputs, and output. This paper offers a brief overview of the historical significance and operational role of the production function in business and economics. The origin and development of this function over time is initially explored. Several various production functions that have played an important historical role in economics are explained. These consist of some well known functions, such as the Cobb-Douglas, Constant Elasticity of Substitution (CES), and Generalized and Leontief production functions. This paper also covers some relatively newer production functions, such as the Arrow, Chenery, Minhas, and Solow (ACMS) functions, the transcendental logarithmic (translog), and other flexible forms of the production function. Several important characteristics of the production function are also explained in this paper. These would include, but are not limited to, items such as the returns to scale of the function, the separability of the function, the homogeneity of the function, the homotheticity of the function, the output elasticity of factors (inputs), and the degree of input substitutability that each function exhibits. Also explored are some of the duality issues that potentially exist between certain production and cost functions. The information contained in this paper could act as a pedagogical aide in any microeconomics-based course or in a production management class. It could also play a role in certain marketing courses, especially at the graduate level.
\end{abstract}

Keywords: Production function; returns to scale; cost functions

\section{INTRODUCTION}

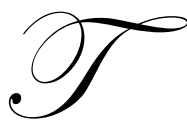

he use of scarce resources is a major topic in economics. The relationship that explains the technology of the firm is called the production function. This function demonstrates the relationship between these scarce resources and the output of a firm. Production theories have existed long before Adam Smith, but were only refined, in a mathematical sense, during the late $19^{\text {th }}$ century. When concerned with a one output firm, the production function is a very simple construct. It tells us the maximum quantity of a particular output that can be produced using various combinations of inputs given certain technical knowledge. We can think of the production function as a type of transformation function where inputs are transformed into output via a managerial process. There are also production sets and input requirement sets that are closely related to the production function, but they will be ignored in this paper. In principles of economics courses, we normally assume that only two inputs exist - labor and capital; this is for pedagogical simplicity only. In most actual production cases, there are many different types of inputs that are instrumental in the production process. As we will see later in this paper, many of the production functions developed can be extended to a multi-input scenario.

In economics, there is a very significance difference between the short run and long run. In some business disciplines, such as finance, a short-term asset is considered one that has a maturity of a year or less and a long-term asset is one with a maturity greater than a year. In economics, calendar time is not relevant in production theory. Theoretical time periods are dealt with in the following manner: The short run is considered that time period where at least one input used in the production process is fixed. This means that it cannot be increased nor decreased. At least one input would be variable in the short run. The long run is considered that time period where all inputs are variable; no inputs are fixed. When using the simple case where only capital and labor are used, it is customary to 
assume that capital is fixed in the short run, thus only labor can be used to change the selected level of output. The normal graphical aid used in showing this relationship is entitled a total product curve. When we enter into the longrun production, isoquants take the place of the role played by the total product curve. When using isoquants, we can allow two different inputs to vary.

Several types of production functions exist. One way to categorize them is they are either fixed or flexible in form. Other common properties that can be categorized are also very important in economics. These include the type of returns to scale that a production function exhibits, the elasticity of substitution, and whether or not it is constant across output levels - the homogeneity, the homotheticity, and the separability of the functions.

\section{HISTORY}

Economics did not begin to become a separate discipline of academic study until at least the time of Adam Smith in the late 1700's. Even then, it was thought of in more general terms than we think of the discipline today. The history before Adam Smith is not deficient of economic writings. Various Roman and Greek authors have addressed many issues in economics, including cursory attention to production and distribution. The Scholastics also devoted substantial time to economic matters, including discussion and inquiries into production. Several authors associated with the Mercantilist and Physiocratic schools of thought also paid even more careful attention to matters of production in the economy. For example, Anne Robert Jacques Turgot, a member of the Physiocrats, is credited with the discovery around 1767 of the concept of diminishing returns in a one-input production function. Diminishing returns is simply another way of stating that the marginal product of an input eventually decreases. Of course, Adam Smith himself devoted much time to issues concerning productivity and income distribution in his seminal 1776 book The Wealth of Nations.

The Classical economists who immediately followed Smith expanded on his work in the area of production theory. In 1815, Thomas Malthus and Sir Edward West discovered that if you were to increase labor and capital simultaneously, then the agricultural production of the land would rise, but by a diminishing amount. They both, in effect, rediscovered the concept of diminishing returns. David Ricardo later adopted this result in order to arrive with his theory of income distribution when writing his economic classic the Principles of Political Economy. The Marginalists also dabbled in the area of production. During the late 1800's, W. Stanley Jevons, Carl Menger and Leon Walras all incorporated ideas of factor value into their books. What these early post-Smith economists all had in common is that they all used production functions that were in fixed proportions. In other words, the capital-tolabor ratios were not allowed to change as the level of output changed. Although interesting, in practice, most production functions probably exhibit variable proportions.

In the 1840's, J. H. von Thunen developed the first variable proportions production function. He was the first to allow the capital-to-labor ratio to change. Von Thunen noticed that if we were to hold one input constant and increase the other input, then the level of output would rise by diminishing amounts. In other words, he applied the concept of diminishing returns to a two-input, variable proportions production function for the first time. An argument could definitely be made that he is the original discoverer of modern marginal productivity theory. His work never received the attention it deserved though. Instead, during 1888, American economist John Bates Clark received credit for being the founder of marginal productivity theory based on his speech at the American Economic Association meetings that year. Shortly after, in 1894, Philip Wicksteed demonstrated that if production was characterized by a linearly homogeneous function (in other words, one that experiences constant returns to scale), then with each input receiving its marginal product, the total product would then be absorbed in factor payments without any deficit or surplus. Around the turn of the century, Knut Wicksell produced a production function very similar to the famous Cobb-Douglas production function later developed by Paul Douglas and Charles W. Cobb. Unfortunately, this was never published in any academic journal and thus he never received any credit for the development of what Cobb and Douglas actually rediscovered in 1928.

In 1937, David Durand built upon the popular Cobb-Douglas production function. The Cobb-Douglas function assumed an elasticity of scale equal to one. In other words, the exponents in their function necessarily summed to one. Durand assumed fewer restrictions on the values of the exponents. He allowed for their sum to be less than, greater than or equal to one. This meant the elasticity of scale was no longer restricted to one. The 
production function could now exhibit increasing or decreasing returns to scale in addition to constant returns to scale.

One other restriction on the Cobb-Douglas production function involved the elasticity of substitution. It assumed the value for this elasticity was equal to unity. In 1961, Kenneth Arrow, H.B. Chenery, B.S. Minhas and Robert Solow developed what became known as the Arrow-Chenery-Minhas-Solow or ACMS production function. Later in the literature this became known as the constant elasticity of substitution, or CES production function. This function allowed the elasticity of substitution to vary between zero and infinity. Once this value was established, it would remain constant across all output and/or input levels. The Cobb-Douglas, Leontief and Linear production functions are all special cases of the CES function. In 1968, Y. Lu and L.B. Fletcher developed a generalized version of the CES production function. Their variable elasticity of substitution function allowed the elasticity to vary along different levels of output under certain circumstances.

Recently there have been many developments with flexible forms of production functions. The most popular of these would be the transcendental logarithmic production function, which is commonly referred to as the translog function. The attractiveness of this type of function lies in the relatively few restrictions placed on items such as the elasticity of scale, homogeneity and elasticity of substitution. There are still problems with this type of function, however. For example, the imposition of separability on the production function still involves considerable restrictions on parameters which would make the function less flexible than originally thought. The search for better, more tractable production functions continues as evidenced by recent academic journal articles on the subject.

\section{CHARACTERISTICS OF PRODUCTION FUNCTIONS}

In explaining some of the history regarding production functions, we mentioned several characteristics that these functions possess. In this section, several of the important characteristics will be explained. The first one that will be covered is the duality between the production function and the cost function. For well behaved functions, we can produce a cost function from a production and vice versa. In other words, under fairly general conditions, the shape of the cost function is a mirror image of the shape of the production function. This implies that the same information on the structure of the production technology can be gathered from either the production function or the cost function. This is important due to the fact that production functions are much harder to estimate econometrically than cost functions. It is very difficult to measure the quantity of capital since it comes in many heterogeneous forms. Cost functions depend on factor prices, which can be expressed simply in one currency, regardless of the actual form of the factor itself, and output levels which are relatively easy to observe.

Another key characteristic of production functions relates to homogeneity and homotheticity. All homogeneous functions are homothetic, but not all homothetic functions are homogeneous. Homogeneity can be of differing degrees. In economics, we typically work with functions that are homogeneous of degree zero or one. If a production function is shown to be homogeneous of degree $\mathrm{k}$, then the first partials of that function would be homogeneous of degree k-1. For example, if we have a production function exhibiting linear homogeneity (degree one), then the marginal product functions would be homogeneous of degree zero, meaning that they are functions of the relative amounts of inputs, but not the absolute amount of any one input used in the production process. Homogeneity also implies that the isoquant curves will be radial blowups of one another. In essence, the curves will be parallel to one another; thus, if a ray was constructed from the origin, the slope of the isoquants along that ray would all be the same. The famous Euler's Theorem also follows from the assumption of homogeneity. The more general homotheticity has an even more important role in economics. Since all homogeneous functions are homothetic, everything just stated above would hold true for homothetic functions as well. Homothetic production functions imply that the output elasticities for all inputs would be equal at any given point. This common value can be represented by the ratio of marginal cost to average cost. Firms with increasing average cost would have output elasticity values greater than one and firms with decreasing average cost would have output elasticities less than one. Under the assumption of homotheticity, all inputs would have to be normal.

Separability is another key potential feature of a production function. Not all production functions can be viewed as being separable. Many production processes use many more than two inputs. This makes studying, such a multi-input function, rather difficult. It would be beneficial if we could break the production process down into 
various stages where intermediate inputs are produced and then combined with other intermediate inputs to produce the final output. If we can specify these separate production functions, then the technology is assumed to be separable. This separability feature has many valuable implications for an economist, including the fact that its presence greatly reduces the number of parameters to be analyzed in an applied economic analysis of cost or production functions.

\section{SUMMARY AND CONCLUSION}

This paper has outlined some of the historically important evolutions in the production function. We saw that writings regarding production began well before Adam Smith contributed his thoughts on the subject, and they continue today in full force.

Production plays a major role in any principles of economics class. One of the first graphical models an undergraduate student is introduced to is the production possibilities frontier. Shortly thereafter, the production function is introduced along with discussions of diminishing returns and returns to scale. At the intermediate level of microeconomics and macroeconomics, production plays an even more important role. Here is where isoquants and isocost lines are normally introduced as well as topics such as the expansion path and perhaps homogeneity. At the graduate level, a more mathematical treatment of the production function is given with careful attention to the various structures of such a function. The relationship of the production function to the cost function is also thoroughly explored at the graduate level.

This paper can also serve as a type of pedagogical aide. It serves as a rough outline of the history behind the production function as well as serving as a listing of some of the more important topics dealt with in production theory.

\section{AUTHOR INFORMATION}

David Gordon, DBA is an assistant professor in the College of Business and Health Administration at the University of Saint Francis (USF), Joliet, Illinois. He teaches both graduate and undergraduate classes in finance and economics. Prior to joining USF he held faculty positions at Illinois Valley Community College, the University of Illinois-Chicago and Governors State University. David was awarded numerous teaching awards during his academic career. Prior to earning his Doctorate in Business Administration he received a MA degree in economics and a BA degree in Finance from the University of South Florida in Tampa. He is currently a member of the American Economic Association, the International Financial Management Association, the National Association of Forensic Economics, the History of Economics Society, the Southern Economics Association and the Southern Finance Association. His research interest includes public finance, labor economics and forensic economics. He has published articles in various business and economics journals.

Richard Vaughan, DM joined the faculty at the University of St. Francis in 2006 after working 22 years in business and earning numerous awards in marketing and operations for a fortune 100 information company. He has served as Director of Marketing with full P\&L ( $\$ 480 \mathrm{M}$ revenue) portfolio management across the nation. Responsibilities included; providing strategic direction, conducting competitive analysis, and developing best in class strategy, structure and process improvement. He has also held several upper level management positions in operations serving fortune 100 customers. Rich received his Bachelor of Arts from DePaul University, his Masters of Science in Management and Organizational Behavior from Benedictine University and a Doctorate of Management in Organizational Leadership from the University of Phoenix. Rich holds numerous technical and project management certificates and is a Registered Communications Distribution Designer (RCDD). He teaches graduate and undergraduate classes in marketing and management both online and in the classroom. His research interests include marketing technology, sustainable business models and strategy development.

\section{REFERENCES}

1. Arrow, Kenneth J. and A. C. Enthoven (1961). "Quasi-concave Programming." Econometrica, Vol. 29, No. 4, pp. $779-800$. 
2. Arrow, Kenneth J., Chenery, H. B., Minhas, B.S., and Robert M. Solow (1971). “Capital Labor Substitution and Economic Efficiency.” Review of Economics and Statistics, Vol. 63, No. 3, pp. 225-230.

3. Berndt, E. and Laurits Christensen (1973). "The Translog Function and the Substitution of Equipment, Structures and Labor in US Manufacturing, 1929-1968.” Journal of Econometrics, Vol. 1, No. 1, pp. 81114.

4. Berndt, E. and Laurits Christenson (1973). "The Internal Structure of Functional Relationships: Separability, Substitution, and Aggregation.” Review of Economic Studies, Vol. 40, No. 3, pp. 403-410.

5. Brue, Stanley and Randy R. Grant (2007). The Evolution of Economic Thought, $7^{\text {th }}$ edition. Mason, OH: Thomson Southwest.

6. Chambers, Robert G. (1988). Applied Production Analysis, Cambridge (UK): Cambridge University Press.

7. Christenson, Laurits R., Jorgenson, Dale W., and Lawrence Lau (1973). "Transcendental Logarithmic Production Frontiers." Review of Economics and Statistics, Vol. 55, No. 1, pp. 28-45.

8. Cobb, C. W. and Paul H. Douglas (1928). "A Theory of Production." American Economic Review, Vol. 18, No. 1, supplemental Papers and Proceedings, pp. 139-165.

9. Diewert, W.E. (1971). "An Application of the Shepard Duality Theorem: A Generalized Leontief Production Function.” Journal of Political Economy, Vol. 79, No. 3, pp. 481-507.

10. Douglas, Paul H. (1948). “Are There Laws of Production?” American Economic Review, Vol. 38, No. 1, pp. 1-41.

11. Durand, David (1937). "Some Thoughts on Marginal Productivity with Special Reference to Professor Douglas’ Analysis.” Journal of Political Economy, Vol. 45, No. 4, pp. 740-758.

12. Friedman, James W. (1973). "Concavity of Production Functions and Non-increasing Returns to Scale." Econometrica, Vol. 41, No. 5, pp. 981-984.

13. Humphrey, Thomas M. (1997). "Algebraic Production Functions and Their Uses before Cobb-Douglas." Federal Reserve Bank of Richmond Economic Quarterly, Vol. 83, No. 1, pp. 51-83.

14. Kmenta, J. (1967). "On Estimation of the CES Production Function." International Economic Review, Vol. 8, No. 2, pp. 180-189.

15. Koopmans, Tjalling C. (1979). "Economics among the Sciences.” American Economic Review, Vol. 69, No. 1, pp. 1-13.

16. Landreth, Harry and David C. Colander (2002). History of Economic Thought, $4^{\text {th }}$ edition. Boston: Houghton Mifflin Company.

17. Lu, Y. and L. B. Fletcher (1968). "A Generalization of the CES Production Function." Review of Economics and Statistics, Vol. 50, No. 4, pp. 449-452.

18. Revankar, N.S. (1971). "A Class of Variable Elasticity of Substitution Production Functions." Econometrica, Vol. 39, No. 1, pp. 61-71.

19. Samuelson, Paul A. (1947). Foundations of Economic Analysis. Cambridge: Cambridge University Press.

20. Silberberg, Eugene and Wing Suen (2001). The Structure of Economics, $3^{\text {rd }}$ edition. New York: McGrawHill.

21. Solow, Robert M. (1957). "Technical Change and the Aggregate Production Function.” Review of Economics and Statistics, Vol. 39, No. 3, pp. 312-320.

22. Thomas, Christopher R. and S. Charles Maurice (2011). Managerial Economics, $10^{\text {th }}$ edition. New York: McGraw-Hill.

23. Zellner, A and N. S. Revankar (1969). "Generalized Production Functions." Review of Economic Studies, Vol. 36, No. 2, pp. 241-250. 
NOTES 